\title{
The effects of oil palm's empty fruit bunch compost with hexaconazole on biomass production and nutrient contents of sweet potato var. VitAto cultivated on sandy soil
}

\author{
Borhan Abdul Haya*, Mohd Yusoff Abdullah, Nur Kharunisa Tajarudin \\ Faculty of Plantation and Agrotechnology, Universiti Teknologi MARA (UiTM), 40450, Shah Alam, Selangor, \\ Malaysia
}

\section{*Corresponding author: borhanyahya@ums.edu.my}

\begin{abstract}
This experiment was conducted to investigate the effects of various treatment combinations consisting of oil palm's empty fruit bunch (EFB) compost and hexaconazole (HEX) on dry mass production, partitioning and nutrient concentrations and contents of sweet potato var. VitAto. The treatments consisted of the recommended inorganic fertilizer for VitAto cultivation (control), solely EFB compost and the combination of treatments consisting of EFB compost with 10 or $30 \mathrm{ppm}$ HEX, using a randomized complete block design (RCBD) replicated four times on sandy soil. The destructive biomass analysis was carried out at 30, 55, 77 and 99 days after planting, which corresponded to the following growth stages, storage root initiation, early and middle bulking and maturity, respectively. The final biomass harvest (99 days after planting) was used for N, P and $\mathrm{K}$ nutrient analysis. The greatest response was observed using EFB compost plus 30 ppm HEX treatment, which significantly increased storage root dry mass production, storage root mass ratio, root to shoot ratio, plant total $\mathrm{K}$ content, storage root $\mathrm{K}$ concentration and content by $16.9 \%, 15.2 \%, 58.8 \%, 75.5 \%$, $69.4 \%$ and $106.9 \%$ at the maturity stage, respectively. The results showed that the control treatment favored the growth of leaf and stem, while the EFB compost with $30 \mathrm{ppm}$ HEX treatment favored the growth of storage root. The EFB treatment was able to supply high $\mathrm{K}$ nutrient to the plant. Both $\mathrm{K}$ and HEX were able to increase the assimilate translocation to storage root and consequently increased the storage root dry mass production. Based on the finding of this study, it is proposed that the EFB compost with 30 ppm HEX combination treatment could be used by farmers as alternative inputs to the inorganic fertilizer application in VitAto cultivation on sandy soil.
\end{abstract}

Keywords: Sweet potato; VitAto, Dry mass production and partitioning; empty fruit bunch; hexaconazole; nutrient concentrations and contents; potassium; storage root yield.

Abbreviation: DAP_Days after planting; F-EFB_Full empty fruit bunch; HEX_Hexaconazole; MARDI_Malaysian Agricultural Research and Development; MPOB_Malaysian Palm Oil Board; OFSP_Orange-fleshed sweet potato; PBZ_Paclobutrazol; ppm_part per million; var._Variety.

\section{Introduction}

The VitAto variety is an orange-fleshed sweet potato (OFSP) which was introduced by MARDI (Malaysian Agricultural Research and Development) in 2007. The name VitAto is the combination of 'VitA' for vitamin A and 'to' for sweet potato (Tan et al., 2010). The VitAto grown under sandy soil generally produces low yield, and this is becoming a major problem faced by VitAto farmers. This low yield consequently contributed to low income obtained by farmers. This study proposed to explore the use of oil palm's empty fruit bunch (EFB) compost and plant growth regulator hexaconazole (HEX) to overcome or minimize the problem of low yield through the understanding of biomass production, partitioning and plant nutrient analysis.

The EFB is one of the wastes or by-products from the processing of fresh fruit bunch (FFB) in the mill (Rosnah et al., 2006). Gross production of EFB in Malaysia was about 21 million tons in 2014 (MPOB, 2015). The EFB has a potential to become a cheap source of fertilizer which is abundantly available and easily obtainable. To date, there was no published report on the effects of EFB on biomass production and partitioning of sweet potato apart from the effects through using chemical fertilizer treatments. The study by Ravoof (1988) only highlighted the general effects of using raw EFB as mulching materials, which resulted in leaf growth reduction but increased the storage root yield under continuous monocropping. Most studies using organic fertilizers reported positive effects on the growth and yield of sweet potato. The $3 \mathrm{t} / \mathrm{ha}$ pacesetter organic fertilizer was shown to increase leaf and storage root fresh weight and dry mass production of sweet potato comparable to the inorganic fertilizer application (Kareem, 2013a). Similarly, the application of 6 t/ha poultry manure was shown to increase total and marketable storage root weight, length and diameter of storage root higher than the control (Agyarko et al., 2014). The information on how the organic fertilizer especially EFB compost affect the nutrient status in sweet potato is also limited. However, many studies have shown an increase in plant nutrient uptake using organic materials. The application of swine manure, sawdust and potato sludge compost mixture was reported to enhance the $\mathrm{N}, \mathrm{P}$ and $\mathrm{K}$ contents of potato tubers compared to a recommended practice of inorganic fertilizer application (Yang et al., 2001). The nutrient 
concentrations of $\mathrm{N}, \mathrm{P}$ and $\mathrm{K}$ in yam leaves were also increased when additional mixture of Siam weed and Mexican sunflower mulch was used (Agbede et al., 2013). The application of compost or poultry manure generally enhanced nutrient uptake either in the leaves of potato (ElSayed et al., 2014) or in the storage root of sweet potato (Agyarko et al., 2014), respectively.

Hexaconazole belongs to the triazole group of compounds, which is commonly used as a fungicide but also has plant growth regulating properties (Jaleel et al., 2008). The HEX effects generally increased plant fresh weight, total, leaf and root biomass, lateral branches, tuberous root yield components, root to shoot ratio, relative growth rate and unit leaf rate of many root crops such as cassava (Gomathinayagam et al., 2007), carrot (Gopi et al., 2007) and sweet potato (Sivakumar et al., 2009). These crops at the same time exhibited reduction in height, leaf area, shoot biomass, leaf and stem number and also shorter internodes.

\section{Results}

\section{Dry mass production and partitioning}

\section{Leaf area and dry mass production}

In general, leaf area, dry mass of leaf, stem, storage root and total were progressively increased from early to maturity stages (Fig 1a, b, c, e and f, respectively). In contrast, root dry mass was initially increased during the period of storage root initiation to middle bulking (77 DAP) stages but later declined (Fig 1d). The total plant and root dry mass were not significantly affected by treatment applications throughout the growth period. The leaf and stem dry mass for the control was significantly higher than other treatments only at the maturity stage. The leaf area for control was significantly higher than F-EFB+30 $\mathrm{ppm}$ at the storage root initiation $(150 \%)$, with F-EFB at the mid bulking stage (33\%) and with F-EFB+10 ppm and F-EFB+30 ppm HEX at the maturity stages $(72 \%$ and $146 \%$, respectively). The storage root dry mass for F-EFB+30 ppm HEX was $17 \%$ significantly higher than control treatment at the maturity stage.

\section{Dry mass partitioning}

The leaf, stem and root mass ratio decreased while storage root and root to shoot ratio increased from the storage root initiation to maturity stages (Fig 2a, b, c, d and e respectively). The leaf and stem mass ratio were not significantly different during the period of storage root initiation to mid bulking stages; however, the control treatment was significantly higher than F-EFB+10 ppm (57\% and $50 \%$, respectively) and F-EFB+30 ppm HEX (120\% and $62 \%$, respectively) at the maturity stage. The root mass ratio was not significantly affected by treatment applications throughout the entire growing period.

The storage root mass ratio for F-EFB+30 ppm HEX was $18 \%$ significantly higher than the control at the maturity stage but no significant differences were observed from the period of storage root initiation to early and mid bulking stages. The root to shoot ratio for F-EFB+10 ppm at the mid bulking and F-EFB+30 ppm HEX at the maturity stages were $59 \%$ and 93\% significantly higher than the control treatment, respectively. However, it was not significantly affected at the storage root initiation and early bulking (55 DAP) stages by treatment applications.
Correlation studies among growth parameters throughout the growth period

Correlation studies among parameters are presented in Table 1. The total dry mass production had significant positive correlations with leaf area, leaf, stem and storage root dry mass production $\left(\mathrm{r}=0.75^{* * *}, 0.77 * * *, 0.90 * * *, 0.96 * * *\right.$, respectively). On the other hand, the storage root dry mass was significantly correlated with leaf and stem dry mass production $\left(\mathrm{r}=0.43^{* *}\right.$ and $0.67 * * *$, respectively).

The total dry mass production was negatively correlated with leaf and stem mass ratio $(\mathrm{r}=-0.87 * * *$ and $-0.68 * * *$, respectively) but correlated positively with storage root mass ratio $\left(r=0.81^{* * *}\right)$. The leaf mass ratio had significant positive correlation with stem mass ratio $(\mathrm{r}=0.74 * * *)$, but negatively correlated with leaf area, storage root mass ratio and root to shoot ratio $\left(\mathrm{r}=-0.55^{* * *},-0.95^{* * *}\right.$ and $\left.-0.81 * * *\right)$. The storage root mass ratio was negatively correlated with stem mass ratio $\left(\mathrm{r}=-0.85^{* * *}\right)$.

\section{Nutrient concentrations and contents}

\section{Nutrient composition in empty fruit bunch compost}

The EFB compost used for treatment composed of 1.01, 0.69 and $1.58 \%$ of N, P and K concentrations, respectively.

\section{Nitrogen, phosphorus and potassium concentrations in various plant parts}

The treatments applied had no significant effects on $\mathrm{N}$ concentrations of leaf, root and storage root as well as $\mathrm{P}$ concentrations of stem and storage root at the maturity stage (Table 2). The $\mathrm{K}$ concentrations of leaf, stem and root for these three treatments; EFB, EFB+10 ppm and F-EFB+30 ppm HEX were significantly higher than the control ranging from 73 to $97 \%, 132$ to $166 \%$ and 100 to $141 \%$ for leaves, stem and root, respectively. Consequently, the $\mathrm{K}$ concentration of storage root in F-EFB $+30 \mathrm{ppm} \mathrm{HEX}$ treatment was $69 \%$ significantly higher than control and $36 \%$ higher, if compared to F-EFB+10 ppm HEX treatment. Both F-EFB+10 ppm and F-EFB+30 ppm HEX increased stem N concentration significantly higher than the control treatment (64\% and 68\%, respectively) and F-EFB (42\% and $45 \%$, respectively). The leaf $\mathrm{P}$ concentration for control treatment was $41 \%$ significantly lower than F-EFB+10 ppm HEX treatment; however, the F-EFB+30 ppm HEX significantly increased root $\mathrm{P}$ concentration higher than the control treatment by $45 \%$.

\section{Nitrogen, phosphorus and potassium contents of various plant parts}

The N, P and $\mathrm{K}$ contents of various plant parts were presented in Table 3. The F-EFB and the combination treatments significantly increased total $\mathrm{K}$ content higher than the control treatment from 22 to $75 \%$. The storage root $\mathrm{K}$ content for $\mathrm{F}-\mathrm{EFB}+30 \mathrm{ppm}$ was $107 \%$ and $62 \%$ significantly higher than the control and F-EFB+10 ppm HEX treatments, respectively. Both control and F-EFB+30 ppm treatment had significantly higher total plant and stem $\mathrm{N}$ content ranging from 12 to $15 \%$ and 51 to $108 \%$, respectively, when compared to F-EFB and F-EFB+10 ppm HEX treatments. The control treatment also had significantly higher leaf $\mathrm{N}$ content than the F-EFB+10 ppm HEX treatment, and at the same time the control and F-EFB significantly enhanced root 
Table 1. Correlation coefficient of various parameters related to dry mass production and yield components as affected by various EFB compost and HEX combination treatments throughout the entire growing stage.

\begin{tabular}{|c|c|c|c|c|c|c|c|c|}
\hline Par. & TDM & LDM & SDM & SRDM & LA & LMR & SMR & SRMR \\
\hline LDM & $0.77 * * *$ & & & & & & & \\
\hline SDM & $0.90 * * *$ & $0.91 * * *$ & & & & & & \\
\hline SRDM & $0.96 * * *$ & $0.43 * *$ & $0.67 * * *$ & & & & & \\
\hline LA & $0.75 * * *$ & $0.98 * * *$ & $0.89 * * *$ & $0.41 * *$ & & & & \\
\hline LMR & $-0.87 * * *$ & $-0.58 * * *$ & $-0.71 * * *$ & $-0.88 * * *$ & $-0.55 * * *$ & & & \\
\hline SMR & $-0.68 * * *$ & $-0.25 n s$ & $-0.37 * *$ & $-0.71 * * *$ & $-0.224 \mathrm{~ns}$ & $0.74 * * *$ & & \\
\hline SRMR & $0.81 * * *$ & $0.29 *$ & $0.48 * * *$ & $0.88 * * *$ & $0.29 \mathrm{~ns}$ & $-0.95 * * *$ & $-0.85 * * *$ & \\
\hline $\mathrm{R} / \mathrm{S}$ & $0.75 * * *$ & $0.27 *$ & $0.43 * * *$ & $0.81 * * *$ & $0.21 \mathrm{~ns}$ & $-0.81 * * *$ & $-0.88 * * *$ & $0.86^{* * * *}$ \\
\hline
\end{tabular}

Significant at ${ }^{*}, p \leq 0.05 ;{ }^{* *}, p \leq 0.01,{ }^{* * *}, p \leq 0.001$ and ns, no significant correlations. The values are the means of four replicates. Par. = Parameters, TDM $=$ total dry mass, $\mathrm{LDM}=$ leaf dry mass, $\mathrm{SDM}=$ stem dry mass, SRDM = storage root dry mass, $\mathrm{LA}=$ leaf area, $\mathrm{LMR}=$ leaf mass ratio, $\mathrm{SMR}=$ stem mass ratio, $\mathrm{SRMR}=$ storage root mass ratio, $\mathrm{R} / \mathrm{S}=$ root to shoot ratio.

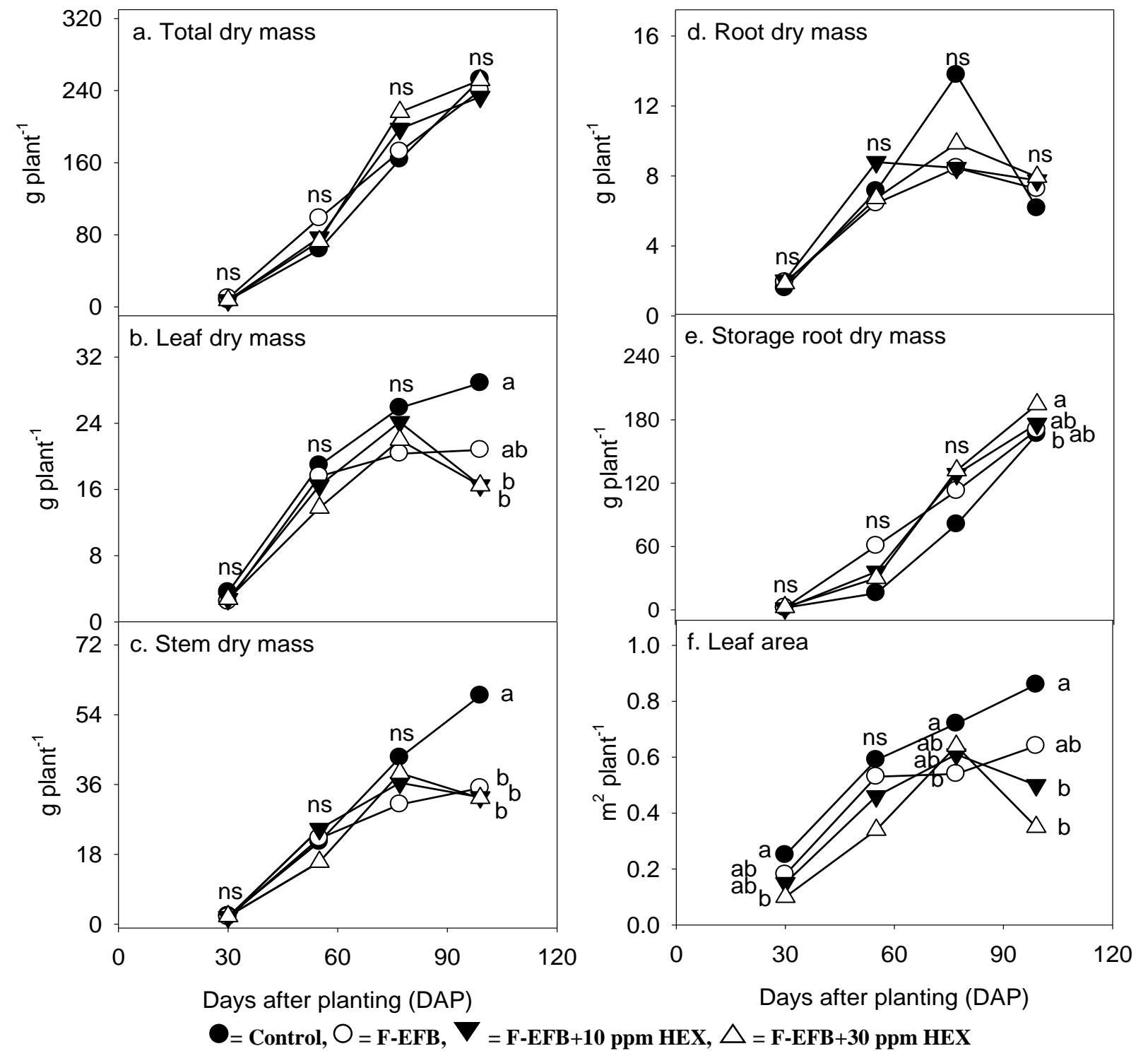

Fig 1. Dry mass production and leaf area as affected by various EFB compost and HEX combination treatments throughout the entire growing stage. Different letters follow different treatments at specific harvest time indicate a significant difference at $p \leq 0.05$, ns, no significant. The values are the means of four replicates. 
Table 2. The mineral nutrients concentrations of various plant parts as affected by various EFB compost and HEX combination treatments at maturity stage.

\begin{tabular}{|c|c|c|c|c|}
\hline Treatment & Control & F-EFB & F-EFB+10 ppm & F-EFB+30 ppm \\
\hline Plant part & \multicolumn{4}{|c|}{ Nutrient concentration (\%) } \\
\hline \multicolumn{5}{|l|}{ Leaf } \\
\hline Nitrogen & $1.58 \mathrm{a}$ & $1.62 \mathrm{a}$ & $1.49 \mathrm{a}$ & $1.63 \mathrm{a}$ \\
\hline Phosphrus & $0.29 b$ & $0.37 \mathrm{ab}$ & $0.41 \mathrm{a}$ & $0.34 \mathrm{ab}$ \\
\hline Potassium & $0.74 b$ & $1.32 \mathrm{a}$ & $1.28 \mathrm{a}$ & $1.46 \mathrm{a}$ \\
\hline \multicolumn{5}{|l|}{ Stem } \\
\hline Nitrogen & $1.66 \mathrm{~b}$ & $1.92 \mathrm{~b}$ & $2.72 \mathrm{a}$ & $2.79 \mathrm{a}$ \\
\hline Phosphrus & $0.24 \mathrm{a}$ & $0.27 \mathrm{a}$ & $0.26 \mathrm{a}$ & $0.26 \mathrm{a}$ \\
\hline Potassium & $0.41 b$ & $1.09 \mathrm{a}$ & $0.95 \mathrm{a}$ & $1.01 \mathrm{a}$ \\
\hline \multicolumn{5}{|l|}{ Root } \\
\hline Nitrogen & $2.72 \mathrm{a}$ & $2.56 \mathrm{a}$ & $2.14 \mathrm{a}$ & $2.18 \mathrm{a}$ \\
\hline Phosphrus & $0.20 b$ & $0.25 \mathrm{ab}$ & $0.28 \mathrm{ab}$ & $0.29 \mathrm{a}$ \\
\hline Potassium & $0.37 \mathrm{~b}$ & $0.74 \mathrm{a}$ & $0.89 \mathrm{a}$ & $0.88 \mathrm{a}$ \\
\hline \multicolumn{5}{|l|}{ Storage root } \\
\hline Nitrogen & $1.89 \mathrm{a}$ & $1.94 \mathrm{a}$ & $1.80 \mathrm{a}$ & $1.86 \mathrm{a}$ \\
\hline Phosphrus & $0.18 \mathrm{a}$ & $0.16 \mathrm{a}$ & $0.13 \mathrm{a}$ & $0.18 \mathrm{a}$ \\
\hline Potassium & $0.62 \mathrm{c}$ & $0.97 \mathrm{ab}$ & $0.77 b c$ & $1.05 \mathrm{a}$ \\
\hline
\end{tabular}

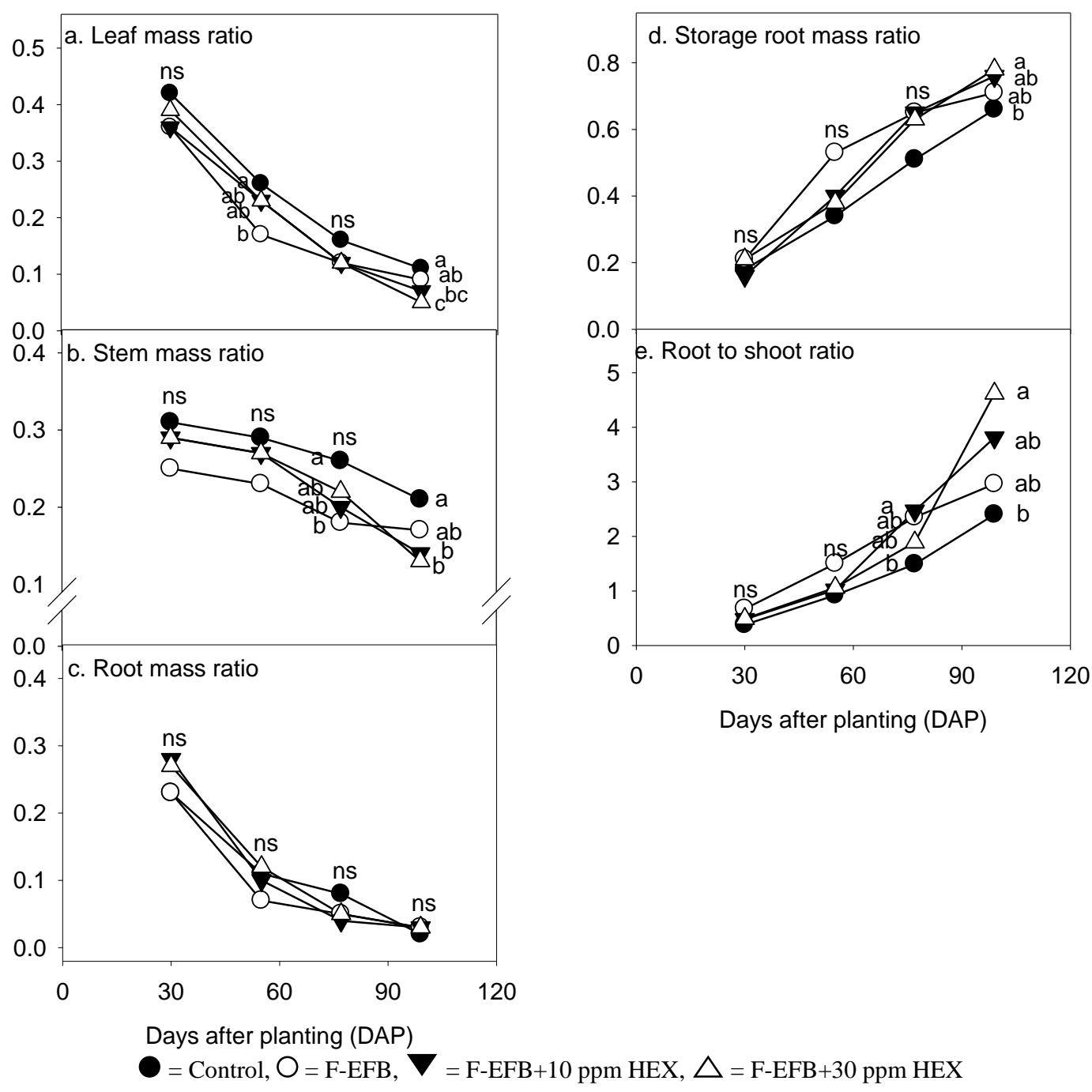

Fig 2. Dry mass partitioning as affected by various EFB compost and HEX combination treatments throughout the entire growing stage. Different letters follow different treatments at specific harvest time indicate a significant difference at $p \leq 0.05$, ns, no significant. The values are the means of four replicates. 
Table 3. The mineral nutrient contents of total and the various plant parts as affected by various EFB compost and HEX combination treatments at maturity stage.

\begin{tabular}{|c|c|c|c|c|}
\hline Treatment & Control & F-EFB & F-EFB + $10 \mathrm{ppm}$ & F-EFB + $30 \mathrm{ppm}$ \\
\hline Plant part & \multicolumn{4}{|c|}{ Nutrient content $(\mathrm{g})$} \\
\hline \multicolumn{5}{|l|}{ Leaf } \\
\hline Nitrogen & $0.45 \mathrm{a}$ & $0.39 \mathrm{ab}$ & $0.27 \mathrm{~b}$ & $0.35 \mathrm{ab}$ \\
\hline Phosphrus & $0.08 \mathrm{a}$ & $0.08 \mathrm{a}$ & $0.06 \mathrm{a}$ & $0.05 \mathrm{a}$ \\
\hline Potassium & $0.21 \mathrm{a}$ & $0.25 \mathrm{a}$ & $0.20 \mathrm{a}$ & $0.21 \mathrm{a}$ \\
\hline \multicolumn{5}{|l|}{ Stem } \\
\hline Nitrogen & $1.25 \mathrm{a}$ & $0.60 \mathrm{c}$ & $0.76 \mathrm{~b}$ & $1.15 \mathrm{a}$ \\
\hline Phosphorus & $0.15 \mathrm{a}$ & $0.10 \mathrm{ab}$ & $0.08 b$ & $0.08 \mathrm{~b}$ \\
\hline Potassium & $0.26 \mathrm{a}$ & $0.43 \mathrm{a}$ & $0.29 a$ & $0.28 \mathrm{a}$ \\
\hline \multicolumn{5}{|l|}{ Root } \\
\hline Nitroge & $0.20 \mathrm{a}$ & $0.22 \mathrm{a}$ & $0.20 \mathrm{ab}$ & $0.15 b$ \\
\hline Phosphorus & $0.02 \mathrm{a}$ & $0.03 \mathrm{a}$ & $0.02 \mathrm{a}$ & $0.01 \mathrm{a}$ \\
\hline Potassium & $0.03 \mathrm{a}$ & $0.07 \mathrm{a}$ & $0.06 a$ & $0.07 \mathrm{a}$ \\
\hline \multicolumn{5}{|l|}{ Storage root } \\
\hline Nitrogen & $3.33 \mathrm{a}$ & $3.21 \mathrm{a}$ & $3.24 \mathrm{a}$ & $3.35 \mathrm{a}$ \\
\hline Phosphorus & $0.32 \mathrm{a}$ & $0.21 \mathrm{a}$ & $0.22 \mathrm{a}$ & $0.30 \mathrm{a}$ \\
\hline Potassium & $1.01 \mathrm{~b}$ & $1.68 \mathrm{ab}$ & $1.29 \mathrm{~b}$ & $2.09 \mathrm{a}$ \\
\hline \multicolumn{5}{|l|}{ Total } \\
\hline Nitrogen & $5.01 \mathrm{a}$ & $4.42 b$ & $4.47 \mathrm{~b}$ & $5.10 \mathrm{a}$ \\
\hline Phosphorus & $0.57 \mathrm{a}$ & $0.40 \mathrm{a}$ & $0.38 \mathrm{a}$ & $0.44 \mathrm{a}$ \\
\hline Potassium & $1.51 \mathrm{~b}$ & $2.43 \mathrm{a}$ & $1.84 \mathrm{a}$ & $2.65 \mathrm{a}$ \\
\hline
\end{tabular}

Values with similar letter within row indicate no significant difference at $p \leq 0.05$. The values are the means of four replicates.

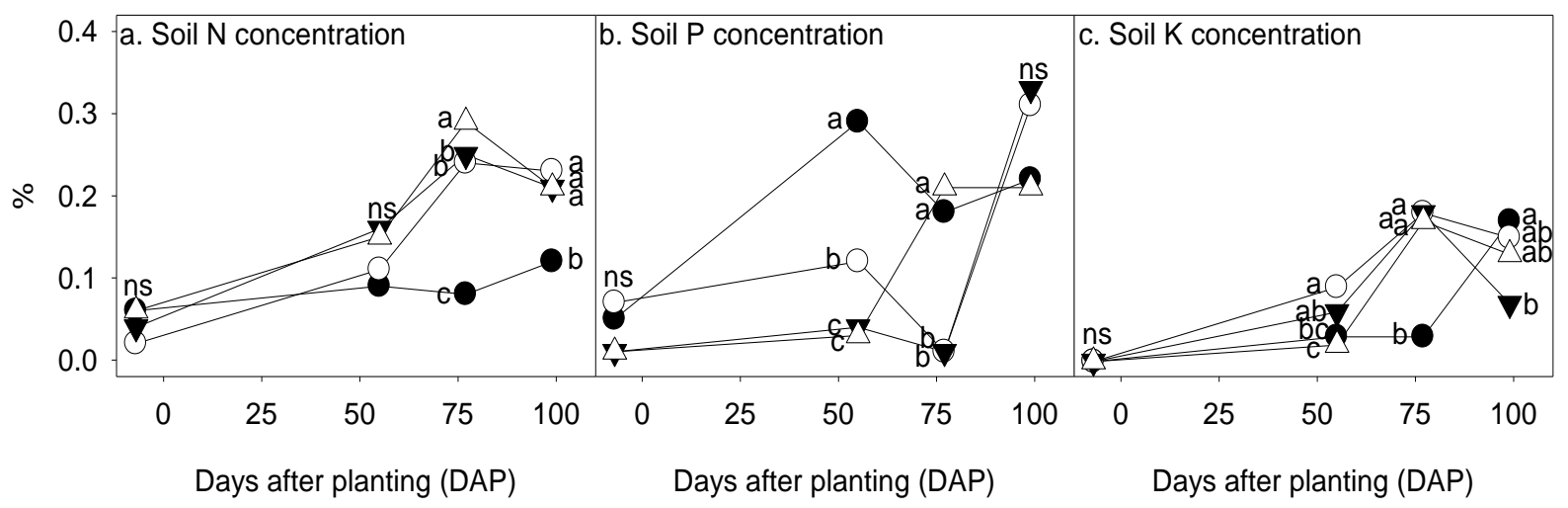

= Control, $\mathrm{O}=\mathrm{F}-\mathrm{EFB}, \boldsymbol{\nabla}=\mathrm{F}-\mathrm{EFB}+10 \mathrm{ppm} \mathrm{HEX}, \triangle=\mathrm{F}-\mathrm{EFB}+30 \mathrm{ppm}$ HEX

Fig 3. Soil mineral nutrients concentrations as affected by various EFB compost and HEX combination treatments throughout the entire growing stage. Different letters follow different treatments at specific harvest time indicate a significant difference at $p \leq 0.05$, ns, no significant. The values are the means of four replicates.

Table 4. Correlation coefficient of various parameters related to dry mass production and nutrient concentrations of various plant parts as affected by various EFB compost and HEX combination treatments at maturity stage.

\begin{tabular}{ccccc}
\hline \multirow{2}{*}{ Parameters } & & \multicolumn{2}{c}{ Dry mass production $(\mathrm{g})$} \\
\cline { 2 - 5 } & \multicolumn{1}{c}{ Leaf } & Stem & Root & Storage root \\
\hline Nitrogen concentration & & & - & - \\
Leaf & $-0.03 \mathrm{~ns}$ & - & - & - \\
Stem & - & $-0.61 *$ & $-0.24 \mathrm{~ns}$ & $-0.56 \mathrm{~ns}$ \\
Root & - & - & - & - \\
Storage root & - & - & - & - \\
Leaf & $-0.01 \mathrm{~ns}$ & - & - & - \\
Stem & - & $-0.11 \mathrm{~ns}$ & $-0.02 \mathrm{~ns}$ & $-0.00 \mathrm{~ns}$ \\
Root & - & - & - & - \\
Storage root & - & - & - & - \\
Phosphorus concentration & $-0.26 \mathrm{~ns}$ & - & - & - \\
Potassium contration & - & $-0.19 \mathrm{~ns}$ & - & $0.24 \mathrm{~ns}$ \\
Stem & - & - & - &
\end{tabular}


Table 5. Correlation coefficient of various parameters related to dry mass production and nutrient contents of various plant parts as affected by various EFB compost and HEX combination treatments at maturity stage.

\begin{tabular}{|c|c|c|c|c|c|}
\hline \multirow{2}{*}{ Parameters } & \multicolumn{5}{|c|}{ Dry mass production $(\mathrm{g})$} \\
\hline & Total & Leaf & Stem & Root & Storage root \\
\hline \multicolumn{6}{|l|}{ Nitrogen content } \\
\hline Total & $-0.20 \mathrm{~ns}$ & - & - & - & - \\
\hline Leaf & - & $0.97 * * *$ & - & - & - \\
\hline Stem & - & - & $0.59 *$ & - & - \\
\hline Root & - & - & - & $-0.90 * * *$ & - \\
\hline Storage root & - & - & - & - & 0.48 \\
\hline \multicolumn{6}{|l|}{ Phosphorus content } \\
\hline Total & $0.51 *$ & - & - & - & - \\
\hline Leaf & - & $0.91 * * *$ & - & - & - \\
\hline Stem & - & - & $0.95 * * *$ & & - \\
\hline Root & - & - & - & $0.62 * * *$ & - \\
\hline Storage root & - & - & - & - & 034 \\
\hline \multicolumn{6}{|l|}{ Potassium content } \\
\hline Total & $0.79 * * *$ & - & - & - & - \\
\hline Leaf & - & $0.64 * *$ & - & - & - \\
\hline Stem & - & - & $0.57 *$ & - & - \\
\hline Root & - & - & - & $0.61 *$ & - \\
\hline Storage root & - & - & - & - & $0.58 *$ \\
\hline
\end{tabular}

Table 6. Correlation coefficient of nutrient contents of total and various plant parts as affected by various EFB compost and HEX combination treatments at maturity stage.

\begin{tabular}{|c|c|c|c|}
\hline \multirow{2}{*}{ Parameters } & \multicolumn{3}{|c|}{ Total nutrient content $(\mathrm{g})$} \\
\hline & Nitrogen & Phosphorus & Potassium \\
\hline \multicolumn{4}{|l|}{ Nitrogen content } \\
\hline Leaf & $-0.14 n s$ & - & - \\
\hline Stem & $-0.24 n s$ & - & - \\
\hline Root & $-0.15 n s$ & - & - \\
\hline Storage root & $0.31 \mathrm{~ns}$ & - & - \\
\hline \multicolumn{4}{|l|}{ Phosphorus content } \\
\hline Leaf & - & $0.31 \mathrm{~ns}$ & - \\
\hline Stem & - & $0.58 \mathrm{~ns}$ & - \\
\hline Root & - & $0.14 \mathrm{~ns}$ & - \\
\hline Storage root & - & $0.82 * * *$ & - \\
\hline \multicolumn{4}{|l|}{ Potassium content } \\
\hline Leaf & - & - & $0.50 *$ \\
\hline Stem & - & - & $0.73 * *$ \\
\hline Root & - & - & $0.56 *$ \\
\hline Storage root & - & - & $0.89 * * *$ \\
\hline
\end{tabular}

Significant at $*, p \leq 0.05,{ }^{* *}, p \leq 0.01,{ }^{* * *}, p \leq 0.001, \mathrm{~ns}$, no significant correlations. The values are the means of four replicates.

$\mathrm{N}$ content higher than F-EFB+30 ppm HEX treatments by $33 \%$ and $47 \%$, respectively.The F-EFB and the combination treatments significantly increased total $\mathrm{K}$ content greater than the control treatment by $61 \%, 22 \%$ and $75 \%$, respectively. The storage root $\mathrm{K}$ content for $\mathrm{F}-\mathrm{EFB}+30 \mathrm{ppm}$ was $107 \%$ and $62 \%$ significantly higher than the control and F-EFB+10 ppm HEX, respectively. The control and F-EFB +30 ppm increased total $\mathrm{N}$ content significantly higher than F-EFB (13\% and $15 \%$, respectively) and F-EFB+10 ppm HEX (12\% and $14 \%$, respectively). The control treatment significantly increased leaf $\mathrm{N}$ content by $67 \%$ higher than the $\mathrm{F}-\mathrm{EFB}+10$ ppm HEX treatment. The stem $\mathrm{N}$ content for the control and F-EFB+30 ppm HEX was significantly higher, if compared with F-EFB (108\% and 92\%, respectively) and F-EFB+10 ppm HEX (64\% and $51 \%$, respectively) treatments. The control and F-EFB significantly enhanced root $\mathrm{N}$ content higher than F-EFB+30 ppm HEX treatments by $33 \%$ and $47 \%$, respectively. The stem $\mathrm{P}$ content for the control was $88 \%$ significantly higher than both F-EFB+10 ppm and F$\mathrm{EFB}+30$ ppm HEX treatments.

\section{Nitrogen, phosphorus and potassium concentrations in soil}

The soil $\mathrm{N}$ and $\mathrm{K}$ concentrations generally increased from a week prior to planting to early and mid bulking stages before declining thereafter (Fig $3 \mathrm{a}$ and $\mathrm{c}$ ). In contrast, soil $\mathrm{P}$ concentration was increased from a week before planting to early bulking stage, followed with a decrease at the mid bulking stage and increased at the maturity stage (Fig 3b). The soil $\mathrm{N}$ concentration was not significantly affected by treatment applications at the early bulking stage but, it was significantly enhanced by F-EFB $+30 \mathrm{ppm}$ higher than other treatments at the mid bulking stage. At the maturity stage, it was significantly enhanced by F-EFB and both combination treatments higher than the control. The control treatment significantly increased soil $\mathrm{P}$ concentration at early bulking stage higher than other treatments, while control and F$\mathrm{EFB}+30 \mathrm{ppm}$ treatments significantly enhanced soil $\mathrm{P}$ concentration higher than F-EFB and F-EFB+10 ppm HEX treatments at the mid bulking stage. In contrast, no significant difference was observed at the maturity stage. The F-EFB 
increased soil $\mathrm{K}$ concentration significantly higher than control and F-EFB+30 ppm HEX treatments at the early bulking stage. At the mid bulking stage, the soil $\mathrm{K}$ concentration was significantly enhanced by F-EFB and both combination treatments higher than the control. At the maturity stage, the soil $\mathrm{K}$ concentration was significantly higher for control if compared to F-EFB+10 ppm HEX.

\section{Correlation studies on the various relationships of biomass production and nutrient analysis at the maturity stage}

In general, nutrient concentrations of various plant parts did not show any significant correlation with their respective dry mass production (Table 4). Among plant part nutrient contents, only $\mathrm{K}$ content of plant parts showed significant correlation with all their respective dry mass (Table 5). Phosphorus content of most plant parts were significantly correlated with their respective plant parts dry mass except for the storage root $\mathrm{P}$ content with storage root dry mass production $(\mathrm{r}=0.34)$. Furthermore, only leaf and stem $\mathrm{N}$ contents had significant correlation with leaf and stem dry mass productions, respectively. Total plant uptake for $\mathrm{P}$ and $\mathrm{K}$ were significantly correlated with total plant dry mass production ( $\mathrm{r}=0.51^{*}$ and $0.79 * * *$, respectively). In contrast, total $\mathrm{N}$ content was negatively correlated with total dry mass production $(\mathrm{r}=-0.20)$. The nitrogen content of most plant parts was negatively correlated with total $\mathrm{N}$ content, while only storage root $\mathrm{P}$ content had significant correlation with total $\mathrm{P}$ content $\left(\mathrm{r}=0.82^{* * *}\right)$ (Table 6). All plant parts $\mathrm{K}$ contents was significantly correlated with total $\mathrm{K}$ content but the highest was for storage root $\mathrm{K}$ content $(\mathrm{r}=0.89 * * *)$.

\section{Discussions}

\section{Dry mass production}

\section{The total plant biomass}

There was no significant response in total dry mass production at the maturity stage as affected by treatments. It showed that the application of F-EFB and the combination treatments increased the production of assimilate comparable to the control treatment in this crop cultivation. There is still a lack of conclusive information on how EFB affects total dry mass production in sweet potato. However, the application of $100 \%$ EFB compost improved dry mass production of 10 month oil palm seedlings in the nursery comparable to those given with mineral fertilizer (AdeOluwa and Adeoye, 2008). The EFB compost increased the total dry mass production of maize higher than inorganic fertilizer application (Palanivell et al., 2013). On the other hand, HEX was shown to increase dry mass production of carrots (Gopi et al., 2007) and Plectranthus forskholii (Lakshmanan et al., 2007).

\section{Vegetative versus reproductive growth stages}

The control treatment generally showed higher leaf area (source capacity) than other treatments in this study. The higher leaf area contributed to higher total dry mass production as indicated by high correlation of leaf area with total dry mass production. Consequently, the higher total dry mass contributed to higher storage root dry mass. Generally, higher total dry mass production is important since it is one of the factors that contribute to an increase in storage root yield (Belehu, 2003).
However, the control treatment in this study exhibited higher leaf and stem but lower storage root dry mass productions as compared to other treatments even after reaching the maturity stage. Similar observation was reported by Serly et al. (2013), where the low production of storage root was due to the excessive leaves and stem growth during the entire cropping period, which competed with storage root development that took place during the middle phase (storage root initiation stage) and the final phase (storage root bulking stage). The reduction of leaves could cause limitation in source capacity, which reduced sweet potato storage root yield as demonstrated by Ruiz et al. (1980). In general, the greater production of leaves the higher the storage root growth (David et al., 1995) and the enhancement of storage root weight also depends on the capacity of leaf photosynthesis (Lebot, 2009). However, under certain situations, excessive foliage or shoot growth could also reduce the root growth (Lebot, 2009).

The storage root dry mass production showed positive response to F-EFB as well as to the combination treatments, especially to F-EFB+30 ppm HEX at the maturity stage. However, their vegetative part dry mass production was lower than the control treatment as indicated earlier. The study by Ravoof (1988) also showed that the application of raw EFB as mulching materials contributed to the low leaf production but high production of storage root yield of sweet potato grown on sandy soil under successive monocropping system. The HEX caused reduction in leaf area of Plectranthus forsklii (Lakshmanan et al., 2007), sweet potato (Sivakumar et al., 2009) and radish (Sridharan et al., 2015). In addition, HEX also reduced leaf and stem dry mass of sweet potato (Sivakumar et al., 2009) and proved to increase tuber or storage root dry mass production of carrot (Gopi et al., 2007), Plectranthus forskholii (Lakshmanan et al., 2007) and sweet potato (Sivakumar et al., 2009).

\section{The total plant biomass in relation to plant dry mass components}

The strong correlation of total plant dry mass with storage root dry mass found in this study was in agreement with the finding of Bourke (1984). Any treatment that can cause an increase in total plant dry mass would definitely increase storage root dry mass production. However, the low yield of VitAto using inorganic fertilization practice as experienced by farmers was not due to the low biomass production but instead was due to a greater allocation of biomass to the above ground, particularly to the stem. This was clearly indicated by an increase of stem dry mass in the control treatment. The stem dry mass was another parameter that strongly correlated with total plant dry mass throughout the entire growth period apart from the storage root as compared to leaf and root dry mass parameters. This study suggested that the main competitive sink for the storage root was the stem. The sink strength of the stem was probably greater than of leaf or root. However, the magnitude of the sink strength may vary depending on the inputs used. The sink strength is the competitive ability of an organ to attract assimilates and the dry mass partitioning was regulated by the sink organs themselves (Marcelis, 1996). The storage root is usually a major or predominant sink organ in sweet potato ( $\mathrm{Li}$ and $\mathrm{Kao}$, 1985; Eguchi et al., 1995) but if the fertilizer applied would increased the sink strength of other plant parts, then the sink strength of the storage root to attract assimilate would be reduced. The control treatment in this study clearly indicated the trend of high stem dry mass with low storage root dry mass production. 


\section{Dry mass partitioning}

\section{Above ground versus below ground biomass}

The partitioning of dry mass to leaf and stem were reduced while to storage root was increased at the maturity stage as shown in this study. Similar findings were reported by other workers (Belehu, 2003; Kareem, 2013b). Solanum tuberosum (potato) is the species that shows similarity in term of growth habit with sweet potato. The leaves of potato has a capacity for self-shedding during tuber enlargement period, which increase the translocation of photosynthates from shoot to tubers and coupled with a stronger pull of tuber as a sink (Djazuli and Tadano, 1990). However, leaf and stem dry mass production for the control continued to increase even when reaching the maturity stage. As a result, the dry mass partitioning to leaves and stem for control treatment were significantly higher than F-EFB+10 ppm and F-EFB+30 ppm HEX, respectively, at the maturity stage. Although at this stage, there was less vegetative growth, along with a reduction in leaf area, and the growth was greater towards reproductive part as reported by many workers (Belehu, 2003; Somasundaram and Santhosh Mithra, 2008; Lebot, 2009).

The storage root mass ratio and root to shoot ratio for $\mathrm{F}-$ $\mathrm{EFB}+30 \mathrm{ppm}$ HEX were significantly higher than the control at the maturity stage, respectively. The treatment that produced high dry mass production with greater drymass partitioning to reproductive parts would result in lower partitioning to vegetative parts and vice versa. As stated earlier, the use of raw EFB as mulching materials contributed to higher storage root yield but lower leaf production (Ravoof, 1988). In general, the slow decomposition process of compost contributes to the slow release of nutrients and consequently prevents excessive growth of vegetative part, which in turn, increases the storage root yield (Leng, 1982). Gibberellin was reported to increase stem elongation and flower formation of Arabidopsis thaliana (Xu et al., 1997), seed germination of Tithonia rotundifolia (Patel and Mankad, 2014) and fruit size of Pyrus pyrifolia (Li et al., 2015). However, gibberellin is also one of the factors that inhibits or delays potato tuber initiation (Davies, 2009), which consequently reduces the sink strength of tuber to attract assimilate and causes a reduction in the allocation and accumulation of dry mass in tubers (Booth and Lovell, 1972). Most fungicides under triazole compounds are capable of enhancing dry mass translocation to below ground part due to their primary action that inhibits gibberellin biosynthesis (Fletcher and Hofstra, 1988). The HEX reduced the leaf and stem dry mass but increased storage root dry mass production and root to shoot ratio of sweet potato (Sivakumar et al., 2009). The application of other triazole compounds such as PBZ also showed similar effects, where assimilate partitioning to stem, leaves, root and stolon were reduced but instead increased to tubers of potato (Tekalign, 2006).

\section{Nitrogen, phosphorus and potassium concentrations general trend}

The $\mathrm{K}$ was the main nutrient that showed positive response to EFB and combination treatments, as compared to $\mathrm{N}$ and $\mathrm{P}$ in this study. The $\mathrm{K}$ concentrations for all F-EFB treatments were significantly higher than the control especially for F$\mathrm{EFB}+30 \mathrm{ppm}$ HEX. Based on the results, it was evident that EFB was high in $\mathrm{K}$, compared to $\mathrm{N}$ and $\mathrm{P}$ concentrations. The result was in agreement with findings from other workers
(Lim and Zaharah, 2000; Salétes et al., 2004). The availability of $\mathrm{K}$ from EFB compost was also higher than $\mathrm{N}$ and $\mathrm{P}$ for plant uptake. It was due to the rapid release of $\mathrm{K}$, while $\mathrm{N}$ and $\mathrm{P}$ were released relatively slower and remained slightly longer than the $\mathrm{K}$ nutrient in $\mathrm{EFB}$, when left to decompost naturally under open area (Salétes et al., 2004). Generally, more than $99 \%$ of $\mathrm{K}$ was released after 10 month of EFB decomposition period (Lim and Zaharah, 2000) and about $73 \%$ of $\mathrm{K}$ was released from EFB during 14 days of storage (Salétes et al., 2004).

The control treatment seemed to perform better for increasing the $\mathrm{N}$ concentrations of most plant parts, while $\mathrm{P}$ concentrations only for the above ground parts as compared to EFB compost and HEX single application in the preliminary experiment. However, the result of this effect was not shown in this experiment because the combination treatments were more effective than the control. This study suggests that EFB compost application should be accompanied with HEX to obtain greater effect of enhancement. It appeared that the application of HEX can further improve the efficiency of nutrient uptake from the fertilizer. The higher nutrient released from EFB, as shown by $\mathrm{K}$ nutrient, probably contributed to higher nutrient uptake by the plant under HEX treatment application. The information on the interactions of HEX with plant nutrient concentrations is limited. However, other triazole compounds such as PBZ was shown to increase leaf $\mathrm{N}$ concentration in Calendula officinalis (Mahgoub et al., 2006), increased the $\mathrm{N}$ but reduced the $\mathrm{P}$ and $\mathrm{K}$ contents of potato tuber (Tekalign, 2006) and at the right concentrations can increase $N$ uptake from fertilizer in wheat (Nouriyani et al., 2012).

\section{Nitrogen, phosphorus and potassium concentrations in soil}

Among soil nutrient concentration values, soil $\mathrm{N}$ and $\mathrm{K}$ generally showed a reduction trend while soil $\mathrm{P}$ increased, when reached the maturity stage. The scenario indicated that the plant $\mathrm{P}$ uptake from the nutrient source was smaller than the uptake of $\mathrm{N}$ and $\mathrm{K}$. This crop is considered tolerant to soils deficient in $\mathrm{P}$ due to higher $\mathrm{P}$ content in the leaves for the longer growth duration (Djazuli and Tadano, 1990). The soil $\mathrm{N}$ concentration for F-EFB and the combination treatments were higher than the control. The high proportion of $\mathrm{N}$ nutrient under inorganic fertilization may be gradually lost through leaching, but in contrast, the EFB and the combination treatments had $\mathrm{N}$ concentration and content higher in the total and various plant parts. Among N, P and K soil nutrients, $\mathrm{K}$ showed the lowest concentration in all treatments. The plant under F-EFB and the combination treatments could have greater absorption of $\mathrm{K}$ as demonstrated by higher $\mathrm{K}$ concentration in plant parts than the control treatment. However, $\mathrm{K}$ for the control could have leached out into the soil similar to $\mathrm{N}$ as discussed above. It was evident that the plant given inorganic fertilizer (control treatment) showed lower $\mathrm{K}$ concentration than those plants under F-EFB and other combination treatments. The cultivation soil was sandy tin-tailing soil with high sands and deficient in most nutrients, poor cation exchange capacity, high soil $\mathrm{pH}$, low water holding capacity, excessive drainage and high surface temperature (Ang et al., 1994; Lim, 2002). Leaching of exchangeable or plant-accessible form of $\mathrm{K}$ ion $\left(\mathrm{K}^{+}\right)$from very sandy soil is high due to inadequate clay or organic matter resulting in insufficient cation exchange bonds to hold those available ions (Vitosh, 1996; Schulte and Kelling, 1998). The K nutrient is highly soluble in water and when water is supplied through the irrigation system or rainfall, it is easily leached out due to the high soil porosity 
characteristic of sandy tin-tailing soil (Ang et al., 1994). The result showed that EFB compost application could improve sandy soil condition in terms of retaining higher nutrients available to the plant as compared to the application of inorganic fertilizer. It has been shown that the available amount of $\mathrm{N}, \mathrm{P}, \mathrm{K}, \mathrm{Ca}$ and $\mathrm{Mg}$ and organic matter in the soil were generally increased with compost application (Sarwar et al., 2008).

\section{Nitrogen, phosphorus and potassium contents in plant}

In general, the total and storage root $\mathrm{N}$ and $\mathrm{K}$ contents responded positively to F-EFB+30 ppm HEX. The leaf and stem $\mathrm{N}$ and $\mathrm{P}$, total and storage root $\mathrm{P}$ contents responded positively to the control treatment. The leaf $\mathrm{K}$, stem $\mathrm{K}$ and most of the root nutrient contents were favoured by F-EFB. It was evident from the results that the application of EFB compost as fertilizer can increase nutrient content in plants. The $\mathrm{K}$ content was the most likely nutrient that can be increased by F-EFB and the combination treatments in all plant parts, whereas, the control treatment improved only the $\mathrm{N}$ and $\mathrm{P}$ contents especially to the above ground parts. The ash of cocoa pod husk and oil palm bunch application have low leaf $\mathrm{N}$ and $\mathrm{P}$ contents but their application at the rate of 4 tons per hectare increased $\mathrm{K}$ content in cocoa higher than the recommended inorganic fertilizer (Akanbi et al., 2014). The high $\mathrm{K}$ nutrient in the soil contributed to higher $\mathrm{K}$ uptake by the plant as shown by F-EFB treatment plant. Furthermore, EFB compost should be applied together with $30 \mathrm{ppm}$ to obtain greater effect since the $\mathrm{K}$ nutrient content were higher for F-EFB+30 ppm HEX than the single application of FEFB.

The relationship between nutrient concentrations and contents with total and plant part dry mass production at the maturity stage

Among total nutrient contents, the total $\mathrm{K}$ was strongly correlated with total dry mass production followed by total $\mathrm{P}$ and lastly total $\mathrm{N}$ content. Among plant parts nutrient content, storage root nutrient content showed a stronger correlation with total nutrient content. This finding is similar to George et al. (2002). Although other nutrients are also important, this study focuses more on $\mathrm{K}$ since it is the most crucial nutrient needed by this crop (FAO, 2005) especially during the period of storage root bulking and maturity. The absence of $\mathrm{K}$ can lead to low yield (FAO, 2005). As discussed, the first factor that can influence the storage root yield is total dry mass production. The second factor that can influence storage root yield is the efficiency of dry mass translocation to storage root (Belehu, 2003). This task can be fulfilled by K nutrient that is responsible in accelerating dry mass translocation to storage root as stated by several workers (Bourke, 1985; George et al., 2002; Kareem, 2013b).

\section{Inorganic versus organic fertilizer application}

As observed in this study, there was no problem in using inorganic fertilizer in VitAto cultivation, because it can produce higher leaf area, which probably contributed to higher production of total dry mass production. However, it becomes a problem when the inorganic fertilizer is needed to further enhance greater growth of vegetative parts beyond the storage root bulking and maturity stages. This is viewed as lack of sufficient $\mathrm{K}$ to accelerate greater dry mass translocation to the storage root as indicated by lower root to shoot ratio in the control as compared to other treatments.
The main problem faced by farmers in sweet potato cultivation is that the plant has longer vegetative growth with shorter reproductive growth periods, when grown in sandy soils which may limit the time for reproductive parts to grow and develop, resulting in smaller storage root than the desirable size (Serly et al., 2013). However, the effect was different when using organic compost because the decomposition process of compost caused slow nutrient release and prevented excessive growth of vegetative part but instead increased storage root yield (Leng, 1982). In the case of EFB, K was generally released rapidly, while $\mathrm{N}$ and $\mathrm{P}$ were released slowly when used in the open field or area (Salétes et al., 2004).

\section{Materials and Methods}

\section{Experimental site description}

Field experiment was conducted at the Malaysian Agricutural Research and Development (MARDI) Rawang, Selangor, during the periods of February to June 2013. The study site was located at about N $3^{\circ} 16^{\prime} 17.89$ ', E 101 ${ }^{\circ} 30^{\prime} 52.19^{\prime \prime}$ and at an altitude of 66 metre above the sea level. The soil type was sandy tin tailing with $90.8 \%$ sand, $4.5 \%$ silt and $4.7 \%$ clay (Vimala, 2005).

\section{Planting materials, treatments and experimental design}

The sweet potato var. VitAto stem cutting around $30 \mathrm{~cm}$ in length were obtained from MARDI Rawang station as planting materials. The treatment used were a standard recommended inorganic fertilizer practice for VitAto cultivation as a control (MARDI, 2008), solely EFB compost (F-EFB) and the combination treatments between EFB compost with 10 or 30 ppm HEX designated as F-EFB+10 ppm and F-EFB+30 ppm HEX, respectively. The N, P and $\mathrm{K}$ contents in Full EFB were analysed before being used as a treatment, which synchronized with those in the control. The experiment was laid out in a randomized complete block design (RCBD) with four treatments replicated four times. The EFB compost (aGricare ${ }^{\circledR}$ Premium Compost) was obtained from Myagri Eco-Biosciences Sdn. Bhd., Selangor, Malaysia. The Anmi4.8SC is a fungicide with HEX as an active ingredient manufactured by Advansia Sdn. Bhd., Selangor, Malaysia. The EFB, 10 and 30 ppm HEX were chosen as treatment or treatment combinations based on findings of preliminary experiment that show a better potential in increasing the yield. The control and EFB compost treatments were applied on 7, 28 and 35 days after planting (DAP) based on MARDI (2008). The HEX treatment was applied using drenching method at 20, 40 and 60 DAP based on procedures by several workers (Gopi et al., 2007; Jaleel et al., 2008; Sivakumar et al., 2009).

\section{Growth analysis procedure}

The destructive growth analysis method (Hunt, 1990) and sequential growth analysis technique (Jolliffe et al., 1982) were used to systematically sampling of plant samples by harvest and ease in field operation. Plant samples were separated into leaf, stem, root and storage root after harvested at 30, 55, 77 and 99 DAP. These sampling days are corresponding to storage root initiation, early and middle bulking and maturity stages respectively. The samples were oven dried at $72^{\circ} \mathrm{C}$ for 48 hours for dry mass determination. The plant samples harvested in the final harvest (99 DAP) were ground into powder using SK 100 standard rostfrei 
pulverizer (Retsch GmbH \& Co.KG, Haan, Germany). The soil samples were obtained at 0 to $20 \mathrm{~cm}$ depth, 8 days before planting and at 55, 77 and 99 DAP, which were air dried and sieved. Plant samples from final harvest and soil samples were used for nutrient analysis.

\section{Leaf area, dry mass production and partitioning} determination

The leaf area and dry mass production data were obtained at 30, 55, 77 and 99 days after planting (DAP). Leaf area was measured using Adobe Photoshop CS6 following Jarou (2009). The leaf, stem, root and storage root dry mass production were measured using AL204 analytical balance (Mettler Toledo, United States). The sum of all plant parts dry mass were used to compute total dry mass production. The leaf area and dry mass production data of various plant parts were used to compute dry mass partitioning parameters. The following formula described by Hunt (1990) and Bhagsari (1990) were used to compute dry mass partitioning data:

- Leaf mass ratio = Leaf dry mass/Total dry mass

- Stem mass ratio = Stem dry mass/Total dry mass

- Root mass ratio = Root dry mass/Total dry mass

- Storage root mass ratio $=$ Storage root dry mass/Total dry mass

- Root to shoot ratio $=($ Root + Storage root dry mass $) /($ Leaf + Stem dry mass)

Leaf, stem root, storage root and total dry mass were measured in gram $(\mathrm{g})$.

\section{Nutrient concentrations and contents determination}

The plant and soil samples were analysed for their concentration and content of macro nutrients $\mathrm{N}, \mathrm{P}$ and $\mathrm{K}$. The $\mathrm{N}$ concentration sample preparation was based on Elementar Analysensysteme $\mathrm{GmbH}$ (2005), while for $\mathrm{P}$ and $\mathrm{K}$ concentrations were based on Campbell and Plank (1998). The sample $\mathrm{N}$ concentration was determined based on combustion method using vario MACRO cube CHNS elemental analyzer (Elementar Analysensysteme $\mathrm{GmbH}$, Hanau, Germany). The samples P and K concentrations were analysed using ICP-OES, Optima 7300 DV (Perkin Elmer, Massachusetts, United State). The nutrient concentrations values obtained from the machine were converted into percentage with proper calculation. The nutrient contents data were derived from the value of nutrient concentrations multiplied with plant parts dry mass productions.

\section{Statistical analysis}

Statistical analysis was performed using one way analysis of variance (ANOVA) followed by Tukey's pairwise comparisons to evaluate the statistical significance multiple comparison data. The relationship between variables was determined using Pearson correlation. Data for dry mass partitioning were determined in ratio form. The $p$ value $\leq$ 0.05 were used to determine levels of significance.

\section{Conclusion}

The problem of using inorganic fertilizer (control) in VitAto cultivation was that the plants tend to increase dry mass translocation more to vegetative parts especially stem as compared to storage root even after reaching the bulking and maturity stages. Lack of $\mathrm{K}$ nutrient absorption by plant under inorganic fertilizer application could be the factor contributed to this problem since the $\mathrm{K}$ nutrient is responsible to enhance the partitioning of dry mass to the storage root. Among the designated treatments, F-EFB+30 ppm HEX was the best treatment that influenced the measured parameters. The F$\mathrm{EFB}+30 \mathrm{ppm}$ HEX generally increased $\mathrm{K}$ concentration and content in most of plant parts better than other treatments. It also seemed to increase dry mass translocation more to storage root instead of leaves and stems. Consequently, the storage root dry mass production for this treatment was higher than the control at the maturity stage. Therefore, the FEFB+30 ppm HEX may be the better option in minimizing the current problem of low yield of VitAto cultivated on sandy soil.

\section{Acknowledgement}

The authors would like to thank MARDI and specifically MARDI Rawang station for providing experimental plot and assistance during the entire experimental period.

\section{References}

AdeOluwa OO, Adeoye GO (2008) Potential of oil palm empty fruit bunch (EFB) as fertilizer in oil palm (Elaeis guineensis $\mathrm{L}$ Jacq) nurseries. Paper presented at the 16th IFOAM Organic World Congress, Modena, Italy. pp. 1620.

Agbede TM, Adekiya AO, Ogeh JS (2013) Effects of Chromolaena and Tithonia mulches on soil properties, leaf nutrient composition, growth and yam yield. W Afr J App Eco. 21(1):15-29.

Agyarko K, Dapaah HK, Buah S, Frimpong KA (2014) Sweet potato (Ipomoea batatas) yield parameters, soil chemical properties and cost benefit ratios following incorporation of poultry manure and inorganic NPK fertilizers in low nutrient Ghanaian soils. Int J Pl Soil Sci. 3(2):129-138.

Akanbi OSO, Famaye AO, Olaniyi OO, Ipinmoroti RR, Iloyanomo CI, Nduka BA, Adeosun SA (2014) Comparative effects of cocoa pod husk and oil palm bunch ash on nutrient uptake, growth and dry matter yield of cocoa (Theobroma cacao) in Ibadan, Southwest Nigeria J Agric Sci. 5:1046-1052.

Ang LH, Chan HT, Darus HA (1994) A cost-effective technique for establishment of Acacia auriculiformis and Acacia mangium on sand tailings. In: Appanah S, Khoo KC, Chan, HT, Hong LT (eds) Proceedings of the International Conference on Forestry and Forest Products Research, 1-2 November 1993. FRIM, Kepong, Malaysia.

Belehu T (2003) Agronomical and physiological factors affecting growth, development and yield of sweet potato in Ethiopia (Doctoral dissertation). Retrieved from Electronic Thesis and Dissertations - UPeTD (University of Pretoria).

Bhagsari AS (1990) Photosynthetic evaluation of sweetpotato germplasm. J Amer Soc Hort Sci. 115(4): 634-639.

Booth A, Lovell PH (1972) The effects of pre-treatment with gibberellic acid on the distribution of photosynthate in intact and disbudded plants of Solanum tuberosum L. New Phytol. 71:795-804.

Bourke RM (1984) Growth analysis of four sweet potato (Ipomoea batatas) cultivars in Papua New Guinea. Trop Agric (Trinidad). 61(3):177-181.

Bourke RM (1985) Influence of nitrogen and potassium fertilizer on growth of sweet potato (Ipomoea batatas) in Papua New Guinea. Field Crops Res. 12:363-375.

Campbell C, Plank C (1998) Preparation of plant tissue for laboratory analysis. In: Kalra YP (ed) Handbook of 
reference methods for plant analysis. CRC Press Taylor \& Francis Group, Boca Raton, Florida. pp. 37-49.

David PP, Trotman AA, Mortley DG, Bonsi CK, Loretan PA, Hill WA (1995) Foliage removal influences sweetpotato biomass yields in hydroponic culture. HotSci. 30(5):10001002.

Davies PJ (2009, May 3) Potato tuberization signals. Why do potatoes tuberize? Retrieved from http://www.potatogrower.com/2009/05/potato-tuberizationsignals.

Djazuli M, Tadano T (1990) Comparison of tolerance to low phosphorus soils between sweet potato and potato. Fac Agr Hokkaido Univ. 64(3):190-200.

Eguchi T, Kitano M, Eguchi H (1995) Effect of air humidity around tuberous root on sink strength in sweet potato plants grown in a solution-air culture system. Biotronics. 24:4549.

Elementar Analysensysteme GmbH (2005) Operating the vario EL: sample preparation. In: Vario EL III CHNOS elemental analyser operating instructions for instruments starting with serial-no.: 11054041. Elementar Analysensysteme GmbH, Hanau, Germany.

El-Sayed SF, Hassan HA, El-Mogy MM, Abdel-Wahab A (2014) Growth, yield and nutrient concentration of potato plants grown under organic and conventional fertilizer systems. American-Eurasian J Agric Environ Sci. 14(7):636-643.

FAO (2005) Crop response to fertilizers. In: Fertilizer use by crop in Ghana. Land and Plant Nutrition Management Service, Land and Water Development Division, Food and Agriculture Organization of the United Nations, Rome, Italy. pp. 25-29.

Fletcher RA, Hofstra G (1988) Triazoles as potential plant protectants. In: Berg D, Plempe M (eds) Sterol biosynthesis inhibitors: pharmaceutical and agrochemical aspects. Ellis Horwood Ltd., Chichester, U.K. pp. 321-331.

George MS, Lu GQ, Zhou WJ (2002) Genotypic variation for potassium uptake and utilization efficiency in sweet potato (Ipomoea batatas L). Field Crops Res. 77:7-15.

Gomathinayagam M, Jaleel CA, Lakshmanan GM, Panneerselvam R (2007) Changes in carbohydrate metabolism by triazole growth regulators in cassava (Manihot esculenta Crantz); effects on tuber production and quality. C R Biol. 330(9):644-655.

Gopi R, Jaleel CA, Sairam R, Lakshmanan GMA, Gomathinayagam M, Panneerselvam R (2007) Differential effects of hexaconazole and paclobutrazol on biomass, electrolyte leakage, lipid peroxidation and antioxidant potential of Daucus carota L. Colloids Surf B. 60:180-186.

Hunt R (1990) Basic growth analysis. Unwin Hyman, London.

Jaleel CA, Gopi R, Panneerselvam R (2008) Biochemical alterations in white yam (Dioscorea rotundata Poir) under triazole fungicides: impacts on tuber quality. Czech J Food Sci. 26:298-307.

Jarou ZJ (2009) Measuring leaf area with Adobe Photoshop $3 . \quad$ Retrieved from http://www.chlorofilms.org/index.php/crpVideo/display/vid eoid/46.

Jolliffe PA, Eaton GW, Doust JL (1982) Sequential analysis of plant growth. New Phytol. 92:287-296.

Kareem I (2013a) Fertilizer treatment effects on yield and quality parameters of sweet potato (Ipomoea batatas). Res J Chem Env Sci. 1(3):40-49.

Kareem I (2013b) Growth, yield and phosphorus uptake of sweet potato (Ipomoea batatas) under the influence phosphorus fertilizers. Res J Chem Env Sci. 1(3):50- 55.
Lakshmanan GMA, Jaleel CA, Gomathinayagam M, Panneerselvam R (2007) Changes in antioxidant potential and sink-organ dry matter with pigment accumulation induced by hexaconazole in Plectranthus forskholii Briq. C R Biol. 330:814-820.

Lebot V (2009) Tropical root and tuber crops: cassava, sweet potato, yams and aroids. Crop Production Science in Horticulture no. 17. CABI Publishing, U.K.

Leng AS (1982) Maintaining fertility by putting compost into sweetpotato mounds. Harvest. 8(2):83-84.

Li JF, Yu XM, Lou YS, Wang L, Slovin JP, Xu WP, Wang SP, Zhang CX (2015) Proteomic analysis of the effects of gibberellin on increased fruit sink strength in Asian pear (Pyrus pyrifolia). Sci Hort. 195: 25 - 36.

$\mathrm{Li}$ L, Kao CH (1985) Investigation of source-sink relationship in sweet potato by reciprocal grafts. Bot Bull Acad Sin. 26:31-38.

Lim JS (2002, 2 November) National report for the UNCCD implementation: combating land degradation and promoting sustainable land management in Malaysia. Retrieved from http://www.unccd.int/RegionalReports/malaysia.

Lim KC, Zaharah AR (2000) Decomposition and N \& K release by oil palm empty fruit bunches applied under mature palms. J Oil Palm Res. 12(2):55-62.

Mahgoub MH, Abd El Aziz NG, Youssef AA (2006) Influence of foliar spray with paclobutrazol or glutathione on growth, flowering and chemical composition of Calendula officinalis L plant. J Appl Sci Res. 2(11):879883.

Marcelis LFM (1996) Sink strength as a determinant of dry matter partitioning in the whole plant. J Exp Bot. 47:12811291.

MARDI (2008) VitAto brochure. Unit Pengeluaran Bahan Tanaman, Biji Benih dan Baka Ternakan (Planting Material, Seed and Livestock Breed Production Unit) Serdang, Malaysia.

MPOB (2015) Total fresh fruit bunch (FFB) received by mill in 2014. Retrieved from http://bepi.mpob.gov.my/index.php/statistics/sectoralstatus/127-sectoral-status-2014/674-ffb-received-by-mill2014.html.

Nouriyani H, Majidi E, Seyyednejad SM, Siadat SA, Naderi A (2012) Effect of paclobutrazol under different levels of nitrogen on some physiological traits of two wheat cultivars (Triticum aestivum L). World Appl Sci J. 16(1):1-6.

Palanivell P, Susilawati K, Ahmed OH, Nik Muhamad AM (2013) Effects of crude humin and compost produced from selected waste on Zea mays growth, nutrient uptake and nutrient use efficiency. Afr J Biotechnol. 12(13):15001507.

Patel RG, Mankad AU (2014) Effect of gibberellins on seed germination of Tithonia rotundifolia Blake. Int J Innov Res Sci Eng Tech. 3(3): 10680-10684.

Ravoof AA (1988) Crop production in sand with oil palm empty fruit bunch mulching. In: Radhakrishna S, Mohinder Singh M, John CK (eds) Proceeding of the 2nd Asian Conference: Technology for Rural Development Kuala Lumpur, Malaysia 4-7 December 1985. World Scientific, Singapore.

Rosnah MS, Wan Hasamudin WH, Ab Gapor MT, Kamarudin H (2006) Thermal properties of oil palm fibre, cellulose and its derivatives. J Oil Palm Res. 18:272-277.

Ruiz ME, Pezo D, Martinez L (1980) The use of sweet potato [Ipomoea batatas, (L) Lam] in animal feeding 1 agronomic aspects. Trop Anim Prod. 5(2):144-151. 
Salétes S, Caliman JP, Raham D (2004) Study of mineral nutrient losses from oil palm empty fruit bunches during temporary storage. J Oil Palm Res. 16(1):11-21.

Sarwar G, Schmeisky H, Hussain N, Muhammad S, Ibrahim M, Safdar E (2008) Improvement of soil physical and chemical properties with compost application in rice-wheat cropping system. Pak J Bot. 40(1):275-282.

Schulte EE, Kelling KA (1998) Soil and applied potassium (A2521), understanding plant nutrients. University of Wisconsin-Madison and University of WisconsinExtension, Cooperative extension Madison, U.S. Retrieved from www.soils.wisc.edu/extension/ pubs/A2521.pdf.

Serly, Sengin EL, Riadi M (2013) 'Respon pertumbuhan dan produksi ubi jalar (Ipomoea batatas L) yang diaplikasi paclobutrazol dan growmore 6-30-30.' Retrieved from http://pasca.unhas.ac.id/.

Sivakumar T, Sundaramanickam A, Panneerselvam R (2009) Changes in growth and pigment content in sweet potato by triadimefon and hexaconazole. J Phytol. 1(5):333-341.

Somasundaram K, Santhosh Mithra VS (2008) Madhuram: a simulation model for sweet potato growth. World J Agric Sci. 4(2):241-254.

Sridharan R, Raja S, Sakthivel P (2015) Effect of triazole compounds on induced changes in growth biomass and biochemical content of white radish (Raphanus sativus L). J Plant Stress Physiol. 1(1):43-48.
Tan SL, Zaharah A, Abdul Aziz AM, Mohsin Y, Zainal Abidin AK, Abd. Hamid I (2010) VitAto - variety keledek kaya dengan ß-Carotina (VitAto - a ß-Carotene rich sweetpotato variety). Buletin Teknol Tanaman. 7:23-33.

Tekalign T (2006) Response of potato to paclobutrazol and manipulation of reproductive growth under tropical conditions (Doctoral dissertation). University of Pretoria.

Vimala, P (2005) Getting started. In: Aini Z, Sivapragasam A, Vimala P, MNM Roff (eds) Organic vegetable cultivation in Malaysia. MARDI, Malaysia. pp. 15-43.

Vitosh ML (1996) N-P-K fertilizers. Extension Bulletin E896. Michigan Cooperative Extension Service, Michigan State University.

Xu YL, Gage DA, Zeevaart JAD (1997) Gibberellins and stem growth in Arabidopsis thaliana: effects of photoperiod on expression of the GA4 and GA5 Loci. Plant Physiol. 114: 1471 - 1476.

Yang JE, Hyun HN, Jung KY (2001, 1 November) Cocomposting potato starch sludge with swine manure. Retrieved from http://www.agnet.org/library.php?func=view\&style= type\&type_id=\&id=2011070614 0127\&print=1. 